\title{
Power and Ideology Revealed in The Awig-awig (Customary Law) Text of Tenganan Pegringsingan Village: Critical Ecolinguistic Study
}

\author{
I Gede Astawa (Corresponding Author) \\ A Doctoral Student of Faculty of Arts, Udayana University, Bali, Indonesia \\ E-mail: gedeastawa@akpar-denpasar.ac.id
}

\begin{abstract}
Made Budiarsa
A Professor of Faculty of Arts, Udayana University, Bali, Indonesia

E-mail: made_budiarsa@yahoo.com
\end{abstract}

I Wayan Simpen

A Professor of Faculty of Arts, Udayana University, Bali, Indonesia

E-mail: wyn_simpen@unud.ac.id

Received: Sep. 16, 2018 Accepted: September 27, 2018 Published: October 18, 2018 doi:10.5296/ijl.v10i5.13656

URL: https://doi.org/10.5296/ijl.v10i5.13656

\begin{abstract}
Awig-awig 'customary law' is a written rule which is used to manage customary village organization in Bali. This customary law has a very important role in maintaining the environment in terms of natural environment (palemahan), social environment (pawongan), and spiritual environment (parhyangan). Therefore, every awig-awig made should be based on Tri Hita Karana (THK) concept. The THK is defined as 'three causes of happiness and prosperity'. In this study, THK is considered as an ecosophy used to judge the existence of lexical items, grammatical contructs, and other linguistic features used in the awig-awig text. In critical discourse, the exisistence of any texts is considered to bring underlying power and ideology. Thus, the written text of the awig-awig belongs to Tenganan Pegringsingan village reveals the form of power fight and ideology. Therefore, this present study was aimed at
\end{abstract}




\section{Macrothink}

International Journal of Linguistics

ISSN 1948-5425

2018, Vol. 10, No. 5

finding the influence of the power domination and ideology revealed in the awig-awig text. By applying a critical discourse analysis, it was found the influence of the power domination depicted by the use of modality kawasa and wenang 'may/can'. Most of the linguistic features used in the awig-awig text bring preservative ideologies that need to be promoted. However, in a small part of the linguistic features used in the text, especially in the social environment, implies destructive ideologies, such as marginalization and patriarchal that need to be resisted.

Keywords: power and ideology, awig-awig, ecosophy, Tri Hita Karana, ecolinguistics 


\section{Introduction}

Language is not only used as means of communication, but also to reveal life reality. Through language, people will get portrayals of certain phenomena. In ecolinguistics perspective, Mbete (2014, p:1) states that language functions as representation of life reality which exists in environment, either sociocultural environment as microcosm, or natural environment as macrocosm. Language and environment are inseparable; they support each other (Haugen in Fill and Mühshäusler, 2001, p:57; Bang dan Døør, 1996, p:1; van Lier, 2004, p:48). From the interaction, interrelation, and independence of language and its environment, emerged the study of language ecology and now more known as ecolinguistics. Ecolinguistics can explore the more general patterns of language that influence how people think about and treat the world (Stibbe, 2015, p:1). The existence of ecolinguistics study becomes a clue to investigate "the stories we live by" which are mental model that influence behavior and lie at the heart of the ecological challenge we are facing (Stibbe, 2015, p:1-2). The stories are conveyed through the choice of lexical items, grammatical constructs and other linguistic features that are standardly used by a particular group (Stibbe, 2015, p:23).

In preserving and protecting the environment, in terms of religious, social, and natural environment, Bali has a representative ecosophy which is well-known as the term of Tri Hita Karana (THK). The ecosophy of THK affirms that happiness, prosperity, and peacefulness are attainable when the three elements of God, human, and nature coexist in harmony with each other in daily life (Peters and Wisnu Wardana, 2013, p:52; Wiana, 2007, p:5-6). The ecosophy of $T H K$ is universal and dynamic that aligns to apply in all situations and era. If this ecosophy can be implemented in real actions by the people in Bali, peace (Shanti) and prosperity (Jagadhita) will be obtained. Besides that, its sustainable implementation will create the society's local wisdom.

The ecosophy of THK has not been comprehensively understood by most people in the society in Bali; as the result, its implementation in daily life is still overlapping. Religious ceremonies that are carried out by the Hindu followers look prominent; however, they are still poor in understanding the meaning and the functions of those ceremonies. Solidarity and mutual cooperation among the people in society are gradually decreasing, since they much more use their time to obtain economic needs. The green land has been changed into buildings that do not portray Bali's beauty landscape. The three problems above indicate that the ecosophy of THK has not been fully implemented in the real life; moreover, for those who have personal interest to get more advantages or profits economically, without caring the sustainability of the environment in the future.

The government of Bali has issued policy to save Bali from distortion of religion, culture, tradition, and environment through the implementation of THK in all areas of life, starting from the structure of social life, religion, and natural environment as cited from Peters and Wisnu Wardana (2013, p:83) as follow.

...the vision of Bali's development is Bali Dwipa Jaya based on THK. Since 1969 THK was established as the fundamental philosophy of Bali's development, which means that all new developments and innovative activities have to be implemented under the 
umbrella of THK. As such THK is incorporated in all kinds of development programs and official policy documents on provincial and regency level such as the regulation of the General Regional Spatial Planning. Even in the law on Tourism of the Republic of Indonesia, the core values of $T H K$ are explicitly mentioned. ....the economic/social, environmental, and cultural/spiritual interests have to be developed in coherence with each other. THK is not so much the single relationships to God, human, and nature, but so much more the interaction and balance between these relationships.

Referring to the statement above, all the customary villages in Bali are obliged to implement THK either in development or daily activities. The outcomes expected from the implementation of $T H K$ are peace and prosperity by the sustainability of the spiritual, social, and natural environment. To ease the government in supervising the implementation of THK in society, all the villages' customary law (awig-awig) must be based on the ecosophy of THK that is regulated in the Regional Regulation of Bali Province Number 3 Year 2003, about customary village (Desa Pakraman).

One of the villages in Bali that has owned an awig-awig since $21^{\text {st }}$ century is Tenganan Pegringsingan village. This village is considered as one of Bali’s original villages (Bali Aga) that has unique culture and tradition. The government determined this village as one of the national cultural heritages. The awig-awig owned by the traditional village of Tenganan Pegringsingan is used to regulate the village's organization due to the rights, obligations, behavior of the society members and the sanctions of violation as well. The awig-awig belongs to the village is obeyed and even considered sacred by the society. One thing that makes the awig-awig differ from the conventional ones that are practiced in most villages in Bali is the recognition of gender equality between male and famale, including rights and obligations. The existence of this awig-awig attracted author's interest to reveal the underlying power and ideology brought by the text

The awig-awig used to govern the customary village of Tenganan Pegringsingan is considered to bring underlying power and ideologi which are able to maintain the sustainability of the natural, social, and spiritual environment. Thus, this study aims at investigating the sociocultural practice of the awig-awig in terms of the influence of power and ideology implied in the text. To obtain the power and ideologi of the awig-awig text, the author applied two relevan theories, namely Fairclough's critical discourse analysis model, and Arran Stibbe's critical ecolinguistics model.

\section{Review of Literature}

Stibbe in his book entitled "Ecolinguistics: language, ecology and the stories we live by" (2015, p:2) states that linguistics provide tools for analyzing the text that surround us in everyday life and shape the kinds of society belong to. These tools can help reveal, the hidden stories that exist between the lines of the texts. Once revealed, the stories can be questioned from an ecological perspective: do they encourage people to destroy or protect the ecosystem that life depends on? If they are destructive then they need to be resisted, and if beneficial they need to be promoted. Stibbe classifies the stories into eight types, namely ideology, framing, metaphor, evalution, identity, conviction, erasure, and salience. In this research, the 
author refers to one of the eight tipes of the story, namely ideology. Stibbe (2015, p:24) further argues that ideology in ecolinguistics analysis, the question is not whether it is true but whether it encourages people to preserve or destroy the ecosystem that support life. The most important discourses to resist are ones which convey ideologies that strongly oppose multiple aspects of the ecosophy, i.e. are considered to play a role in ecological destruction, and are highly widespread. In this study, such discourses are referred to as distructive discourses.

Wodak (2001, p:10) states that language is not powerful on its own - it gains power by the use of powerful people make of it. He further argues that ideology in critical linguistics (CL) is seen as an important aspect of establishing and maintaining unequal power relations. CL takes a particular interest in the ways in which language mediates ideology in a variety of social institutions.

Trčková (2016) conducted a study entitled "Representation of Nature in Ecotourism Advertising". The purpose of his research is to reveal descriptions of the dominance of nature and human and natural relations in ecotourism advertisements. The results of the analysis show that the advertisement study in this study adopts a number of discursive devices that empower nature and oppose human construction that dominates nature. This requires evaluative lexis evoking respect and humbleness towards nature, namely the construction of the natural images as an aesthetically stunning work of art and the realization of supernatural qualities, presented basically as an object of tourists' views, renewal and admiration. Other evaluative meanings with the influence of empowerment include prosperity, purity, fertility, and health. The advertisement also repeatedly adopts a number of transitivity configurations that are empowering, such as moving signs and driving experiences, and allocating agentive roles in the construction process of natural elements of inanimate objects, which represent nature as a provider, creator, and something that thrives. The human-nature divider is also expanded in the application of the description of natural phenomena which equate nature with wilderness, far from civilization, pure and untouched by humans. So, nature tends to be described as the others, separate from humanity, blocking the holistic view of both. When the interaction process is used, rather than stating that humans and natural phenomena interact with each other, the role of actors is allocated solely to humans, with nature describing the interactional processes that are affected. Furthermore, the form of transience in which humans have a role as actors (actors) and nature has a role as a goal repeatedly adopted in the data, an inverted transitivity in which humans occupy the role of goals (processes) of the process, actors from the process of nature, lost. Overall, the tourism advertisement ecotourism studied seems to construct the boundary between humans and nature, maintaining a dichotomy between the two.

Qiu (2013) conducted a reseach entitled "A Critical Study of English Eco-hotel Profiles Based on Fairclough's Three-dimentional Model". Qiu conducted a critical study of eco-hotels to describe the ecological ideas listed in the profiles of several hotels. The reseach found: firstly, the English eco-hotel profiles make use of various linguistic resourses, among which, material processes and relational processes under transitivity are most frequently used. Material processes are mainly used to inform potential consumers of the nature-oriented efforts and actions the eco-hotels have taken; relational processes are largerly employed to 
promote and highlight the unique natural environment where eco-hotels are located and the spiritual enjoyment brought to the guests by history and culture. All these linguistic resources work together to persuade the prospective customers into paying a visit to the eco hotel for a unique and ecology friendly experience. Secondly, all the linguistic resourses used in English eco-hotel profiles help to express certain kinds of ecological thoughts. Thirdly, in a society replete with ecological crises and irrational people who chase only the material comfort, those are urgently needed who speak for nature and propagate nature-friendly lifestyle. Eco-hotel founders, therefore, may gain both fame and fortune, thanks to the ecological thoughts they express through the language use in their eco-hotel profiles. Thus, they, as profit-seeking businessmen, are voluntary to express and disseminate ecological thoughts or consciousness. This reseach also found that the language use help to convey ecological thoughts or ideologies, which may in turn influence or manipulate readers' ecological ideologies by changing their "human-centered” values into "eco-centric” world view.

\section{Methodology}

This study applied qualitative method. Data collection method used in this study was documentation method. The data was taken from the written text of the awig-awig 'customary law' of Tenganan Pegringsingan village. Through this documentation study, the author collected relevant data regarding to the focus of the research. The influence of the power and ideology revealing in the awig-awig text was investigated through the linguage features used regarding to human relations with the environment (palemahan), human relations with human (pawongan) and human relations with God (parhyangan). This documentation method was carried out with a note-taking technique that aims to dissect the underlying power and idiology of the awig-awig text itself. The data collected were analized by using critical discourse analysis proposed by Norman Fairclough and critical ecolinguistics proposed by Arran Stibbe.

\section{Analysis of Sociocultural Practice of the Awig-awig}

Sociocultural practice gives a general description of the position of language in a social community. Language in society centrally has power, and is a means for achieving power. In addition, language also has its own ideology (Fairclough, 2003, p:19).

\subsection{Power}

The presence of a discourse, either in the form of text, conversation or other forms, is not seen as something natural, reasonable, and neutral but is a form of power struggle. The concept of power is one of the key relationships between discourse and society. Language is not only analized by describing the aspects of the language, but also by connecting with the context. Context here means that language is used for certain purposes and practices, including the practice of power (Eryanto, 2001, p:7). According to Fairlough (2003, p:53), power in discourse is related to the controls and restrictions that are carried out by participants who own power over participants who do not. There are three types of restrictions that can be clearly distinguished. The first is content, that is, what is said or done. The second is the relationship, namely the relationships that people put into the discourse. The third is the subject or 'subject position' occupied by someone. Furthermore, Eriyanto 
(2001, p:272) explains that power is based on ownership of valuable sources such as money, status and knowledge. This premise states that the factors of money, status and knowledge are very possible to be used as instruments for domination.

Domination is a form of coercion due to social force by a group of people who are in this case a minority group. The issue of relations and / or integration between the dominating group and the dominated group will be one of the main factors including critical discourse analysis studies. In connection with this, the lingual form reflected in the use of words, structure and form of certain sentences is not seen merely as a technical problem of grammar or linguistics, but an expression of domination, namely an attempt to form public opinion, affirm, and justify one's own or ostracize others. Thus, the awig-awig text and the power of communication that is owned will tend to be used as a tool to dominate weak parties (text consumers) through language tools (van Dijk, 2008, p:6). The form of power and domination in the awig-awig text is realized with modalities like the example in the following citation.

(1) //...tingkahing wong désa ika sinalih tunggal, tingkahing makagélanang sanak nia, yaniya wus asrah katampi sadah suhunan, yan iya waduning mangalésin tan kawasa... yan lanangé mangəlésin kawasa...//

\section{(ADATP-04)}

'... regarding the villagers betrothing their children, if they have already handed over the sedah suhunan 'betel nut and its equipment ', if the woman's party cancels the engagement is prohibited ... if the man's party cancels the engagement is allowed ...'

Citation (1) above is a form of power in the language that is used by the text producers to other participants, namely the consumers of the text. By using a lingual unit in the form of a negative modality tan kawasa 'forbidden', the text producers do hegemony to other participants, namely an engaged woman is not permitted to cancel her engagement with a man if the ritual sadah suhunan has been handed over. The power domination used by the text producers for the violation is the fine imposed by the village on the woman's side. On the other hand, the power domination carried out by the text producers is also shown in lingual units in the form of the clause yan lanangé mangalésin kawasa 'if the man who cancels it, it is allowed'. The clause above is implicitly a form of marginalization of rights between men and women where the producers of the text show their alignment to men. The women in this text are positioned weaker than men's groups.

(2) //...tan kawasa wong désa ika sinalih tunggal anyandayang, muah angadol carik, abian, pakarangan;...//

(ADATP-07)

'....anynone is not permitted to pawn or sell rice fields, gardens, or house compound;...'

The power domination forms used by text producers in quotation (2) are to prohibit anyone from the village of Tenganan Pegringsingan from selling and pawning the rice fields, gardens, 
or home yards. Implicitly, the prohibition of land pawning and selling is a preventive step taken by text producers so that lands in Tenganan Pegringsingan area do not change hands, either because they are pawned or sold. All land occupied by Tenganan Pegringsingan Village is communal in nature which is inherited from their ancestors which cannot be transferred to people from outside the village with any purposes.

(3) //...yan ana wong désa iki sinalih tunggal molaksana mamaling, tka wənang wong désa iki sinalih tunggal kadanda gung arta 10.000; kang kamaling wonang mantuk minggal//

\section{(ADATP-03)}

'... if one of the villagers steals something, thus, the doer is fined ten thousand rupiahs, the stolen goods must be doubly returned'

The lexicon wenang 'permitted' in citation (3) illustrates the power domination to other participants who are a minority group in the discourse. Because the text producers represent the community, they can use their power as a dominant group, forcing minority groups to pay fines for stealing. By using modality wenang 'permitted', what is done by the text producer has absolute truth values that must be obeyed by anyone who commits theft.

(4) //...tingkahing wong désa ika sinalih tunggal angrangkatang janma akagélan tan kawasa, tur tka wənang kadanda olih désall

\section{(ADATP-05)}

'...regarding one of the villagers marrying a woman who is still tied by an engagement with another man is not permitted; thus, the violator should be fined by the village'

The Lingual unit in citation (4), angrangkatang janma akagélan tan kawasa 'marrying a woman who is still tied an engagement with another man is 'not permitted' shows the power of the text producers in giving sanctions to anyone in Tenganan Pegringsingan village who marries a wowan who is still tied an engagement with another man. Implicitly, the force realized through the use of negative modality tan kawasa 'not permitted' has the aim at creating a safe social environment, no disputes between people, and maintaining a harmonious social life among people. Producers of the text take preventive actions so that there are no problems triggered by romance problems, so as to create a safe and comfortable social life in Tenganan Pegringsingan village area which is in line with the ecosophy of THK, namely creating harmonious social enviroment.

(5) //...yan ana wong désa ika sinalih tunggal mengambil misan kahanggén somah, pada tan kawasa, yan ana amurug, kawənang kakésahang olih désa, tan kawasa agənah ring Desa Tenganan Pegringsingan, tur tan wanang anyungsung kayangan ring Tenganan Pegringsingan manut trap kadi saban //

(ADATP-16)

'...if anyone of the villagers marries to a cousin as a wife or husband is truly 
prohibited. If anyone violates it, the village has a right to drive him/her away, it is not permitted to live in Tenganan Pegringsingan village, even pray in the temples in Tenganan Pegringsingan based on the valid rules’

The force in discourse shown in citation (5) is illustrated by intermarriage prohibition by the text producers. Participants who are a minority group do not have the power to oppose this condition. For text producers, inter-cousin marriages have an adverse effect on decency, so they need to be prohibited. For text the text consumers, marriage is a human right. As the dominant group that represents the community, the text producers even give very severe sanctions to the groups that violate the customary rules. This is indicated by the clause kawənang kakésahang olih désa, the village has a right to drive away' tan kawasa agənah ring Tenganan Pegringsingan 'it is forbidden to live in Tenganan Pegringsingan', tur tan wonang anyungsung kayangan 'may not offer prayers at the holy places in Tenganan Pegringsingan '.

(6) //...wong Désa Tenganan Pegringsingan yaniya cucaka, tan kawasa iya milat masangkapan ring Bale Agung, saika pamarginé saking kuna/l

(ADATP-29)

'... the people of Tenganan Pegringsingan village, if they are disabled, they are prohibited from attending the meeting at Bale Agung 'traditional pavilion meeting'; that is the implementation from the past'

Citation in (6) above depicts the domination power of the text producers that marginalize the people with physical disabilities, by not allowing them to participate in the customary meetings in the Bale Agung 'traditional meeting pavillion' of Tenganan Pegringsingan Village. There are restrictions on the rights between normal people and abnormal ones in social life. The form of parallelization can be observed from the lingual yaniya cucaka tan kawasa iya milat masangkapan ring Bale Agung 'if he is disabled it is prohibited to attend a traditional meeting in Bale Agung'. The text producers are positioned as successors to traditions that have been inherited from generation to generation. This can be observed from the clause saika pamarginé saking kuna 'that is how it was done from the past'.

\subsection{Ideology}

The functions and meanings of the language ideology of a particular language environment are related to individual mental, collective mental, cognitive, ideological systems, and psychic systems (Lindø and Bundsgaard (eds.), 2011, p:11). The ideological analysis of the awig-awig text used an analytical approach that refers to ideology in the ecolinguistic perspective proposed by Stibbe (2015), where ideological analysis on ecolinguistics is not solely seeking whether certain ideologies are right or wrong; however, whether ideologies implied in the text correspond to the ecosophy or not.

\subsubsection{Preservative Ideology}

The re-compilation of the awig-awig text was previously burned and there were no duplicates left that could be used as references. Therefore, the rearrangement was only based on the text 
produsers' memory. If it is deeply observed, the reconstruction of the awig-awig text is not well structured. However, with its simple language and formulation, there are meanings and preservative ideologies in maintaining the sustainability of the three environmental domains, namely the natural environment, social environment and spiritual environment. Although when the awig-awig was rewritten, the people of Tenganan Pegringsingan village had not known the ecosophy of THK; however, if examined in depth, the substantial content of the awig-awig, either explisitly or implisitly, depicts efforts to prevent the environmental damage.

\subsubsection{Preservative Ideology on Natural Environment (Palemahan)}

Interaction, interrelation, and interpedence of Tenganan village community with the environment is prominent in everyday life. The natural environment with its contents, either biotic or abiotic depicts "stories we live by" that are carried out by the community by showing respect to the nature where ecosystem depends on. Preserving and caring the environment is one of the local wisdoms of the community that has been practiced and rooted from generations to generations. This is an evidence of the obedience of Tenganan Pegringsingan village community against the awig-awig belongs to the village. The following citations are meanings and ideologies that reveals environmental preservation dimensions (palemahan).

(7) //...tan kawasa wong désa ika sinalih tunggal anyandayang, muah angadol carik abian pakarangan;...//

(ADATP-07)

'... anynone is not permitted to pawn or sell rice fields, gardens, or house compound;...'

The lingual unit anyandayang, muah angadol carik, abian, pakarangan 'pawning or selling rice fields, gardens, or yards' in citation (7) is prohibited by text producers. Text producers consider that the need to keep the inheritance of the ancestors in order to remain as inherited. The ideological ideas revealed in it are environmental preservation that must be maintained by Tenganan Pegringsingan village community. This is a preventive action so that paddy fields, gardens, and home yards that have provided great benefits to the lives of the Tenganan Pegringsingan villagers do not change hands to other people who are not native citizens of Tenganan Pegringsingan village. The beauty of the environment as an ethnic peculiarity must be maintained as mandated by the ancestors of Tenganan Pegringsingan village which is realized through lingual units in the awig-awig text.

(8) //...né sedawuh pangkung sabalér désa tan kawasa ngarabah jaka kari mabiluluk, yan wus talas bəluluk ipuné ika jakané wənang rabah; yan ana amurug angerebah kayu muah jaka, wənang kang amurug kadanda olih wong désa...//

(ADATP-14)

'... the trench in the West, the northern part of the village, cutting down palm trees that are still flowering is forbidden; if the trees have finished producing fruit, they can be cut down; If someone violates, cutting down trees or palm trees, the violator should 
be fined by the village ...'

The ideological ideas revealed in the citation (8) ... tan kawasa ngarabah jaka kari mabiluluk, ... 'It is not permitted to cut down flowering or fruiting palm trees' is the preservation of the existence of palm trees. The existence of the palm trees has a lot of functions ranging from stems, sago, palm fiber, midrib, and until the leaves. From the flower stems can be tapped to produce tuak 'fermented alcoholic beverages from sap' which is a cultural symbol of Tenganan Pegringsingan village community. The tuak is a means of offering in certain ritual or ceremonies. The tuak produced from palm trees is also a cultural symbol in the form of tuak party committed by the community members. This tuak drinking event implies an ideology to strengthen the relationship among the community members. The Tuak becomes a media used to socialize among the cummunity members, besides having a palm tree conservation function in the hilly area that surrounds Tenganan Pegringsingan Village. If needed, palm trees in the western part of the trench and the north of the village are allowed to be cut down as long as the palm trees are not flowering. From the above quotation, it can be observed the strength of interrelation, interaction, and the interpedence of the environment with humans through the symbol of language and culture which is considered the local wisdom of Tenganan Pegringsingan village community. There is a strong relationship between the existence of palm trees as forest protectors and the culture of tapping palm trees to get the tuak. There are rituals that use the medium of tuak as an offering, and the drinking of tuak among the community members as a symbol of harmony and a way to socialize. Thus, the environment is not an entity that is separate from humans, from socio-cultural life, or language.

\subsubsection{Social Environment (Pawongan)}

In the social environment dimension, the awig-awig text also has the meaning and ideology of maintaining human relations with other humans. The relationship built is to create a sense of comfort and peace. Humans as social beings always require interaction, interrelation, and interpedence with other humans. The influence of globalization nowadays is growing rapidly which contributes to socioecological changes; however, the social and ecological impacts associated with the use of the language and life of the local language in this case can be said not to have significant changes. The social relations built between one human to another one can be observed in the following citation.

(9) //...tingkahin wong désa ika sinalih tunggal angrangkatang janma akagélan tan kawasa//

ADATP-05)

'...regarding one of the villagers who marries a woman who is still tied by an engagement with another man is not permitted'

The Lingual unit in citation (9) angrangkatang janma akagélan tan kawasa 'marrying people who are engaged is forbidden' implies an ideology of creating life in harmony among the people of Tenganan Pegringsingan village. Text producers expect the people to avoid social conflict by not marrying a woman who has been engaged to another man. Small problems have 
the potential to create disharmony among the people, thus, a preventive action is needed in the form of prohibition of marrying a woman who has been engaged to another man.

(10)//...wongé mengandok ring prabumian Tenganan Pegringsingan, sane kasukén antuk désané gənah mangarapin mawasta ring Banjar Pandé,...//

(ADATP-35a)

'... the migrants in the village of Tenganan Pegringsingan are given a housing complex named Banjar Pande ...'

Citation (10) implies an ideology of building good relationships with migrants who make a living in Tenganan Pegringsingan village. Text producers want to maintain harmony between indigenous people and immigrants. This can be observed from the lingual unit kasukén antuk désané gənah 'given a place for living by the village community'. The lingual unit kasukén antuk désané gənah 'given a place for living by the village community' has a deep ideological meaning, the people of Tenganan Pegringsingan village accept the existence of the wongé mengandok 'migrants' from outside the village who want to live and make a living in Tenganan Pegringsingan village. The migrants are allowed to accupy a housing complex named Banjar Pande. The sense of community solidarity is very high where the migrants are given opportunities to use their potential to make a living as long as obeying the awig-awig belongs to the village. The above citation implies a harmonious relationship between Tenganan Pegringingan village community and immigrants to create a comfortable, safe and peaceful social life.

(11)//...tingkah I wong Désa Tenganan Pegringsingan tan kawasa bəlas makurənan, wiwah yan ana amurug sinalih tunggal, tka wənang iya kakésahang saking Désa Tenganan, manut kadi kuna//

\section{(ADATP-49)}

'... the people of Tenganan Pegringsingan village are forbidden to divorce. If there is one who violates it, he/she should be expelled from Tenganan Pegringsingan in accordance with the previous comitted rules'

The ideology revealed in the clause tan kawasa balas makurənan 'forbidden to divorce' in citation (11) is to prevent social conflicts among community member. For the people of Tenganan Pegringsingan, all the the community members are families who must be kept intact. Divorce is believed to cause disputes between the two parties involved. In addition, the meaning and ideology of being faithful to the partner is revealed in the awig-awig text. By being faithful to the partner in a marriage, a happy and comfortable life will be realized. The expectation of the text producers is to achieve a comfortable social environment, thus, with the power of the language they possess, the text producers use the power domination in language by evicting from the area of Tenganan Pegringsingan village for those who divorce in their marriage. This condition can be observed from the lingual kakésahang saking Désa Tenganan 'expelled from the village of Tenganan Pegringsingan'. 


\subsubsection{Religious Environment (Parhyangan)}

In the dimension of human relations with the Almighty God, the Creator of the universe, Tenganan Pegringsingan villagers show gratitude by carrying out various kinds of ceremonies or rituals which are done with a sense of sincerity. Gratitude is inseparable from the realization of God's grace that has created a fertile region with various crops for the survival of the people's lives. Implicitly, examples of human relations with the Almighty God can be observed from the following citation.

(12)//...tatkalaning wong désa ika sinalih tunggal ngawéntənang pujakérti ring Désa Tenganan Pegringsingan ring sasih Kalmia, tka wənang sapalasan pakarangan Tigasana kasalarin antuk wong désané ring Tenganan Pegringsingan...//

\section{(ADATP-13)}

'...if anyone in the village is carrying out a worship in Tenganan Pegringsingan village in the' fifth month ', it is appropriate that the Tigasana village area is obliged to donate the crops which are collected by the people of Tenganan Pegringsingan village...'

The meaning and ideology revealed in the citation (12) above is the awareness to make sacrifices to the Creator of the universe. The use of the material process kasalarin 'donated / financed' in the clause wənang sapalasan pakarangan Tigasana kasalarin antuk wong désané ring Tenganan Pegringsingan 'obligated for the area of the Tigasana to be financed by the people of Tenganan Pegringsingan' is one form of devotion of the people in Tenganan Pegringsingan village as God's creature that has been granted fertile nature as a source of livelihood for all people. The salaran 'donation' offered in the ceremonies or rituals is the crops yielded in the territory of Tenganan Pegringsingan Village. The salaran is a representation of gratitude to God for the crops that become a source of livelihood for the people in Tenganan Pegringsingan village that depict their ethnic identity.

(13)//...kang né mangəndok sasorohan makarya saluiré, wənang kang mangdok pakaryan, wənang iya anyarongin sapuja caruné ring Pande, sanangkən sasih kalima manut trap kadi saban//

(ADATP-22)

'...immigrants as workers, for example, it is compulsory for the immigrants who are seeking jobs participate in all the traditional / religious ceremonies in Banjar Pande every fifth month according to the valid customary rules'

The meaning and ideology revealed in citation (13) is that the migrants in Tenganan Pegringsingan have the awareness to participate in all the ceremonies or rituals in Tenganan Pegringsingan village. Getting closed to the Almighty God should be done wherever humans are, not limited by distance and time. Like the proverb says "where the earth is stepped on, there the heavens are upheld" becomes an understanding for anyone from outside who lives in Tenganan Pegringsingan village to join in upholding and following all ritual or ceremonial activities, as shown by the lingual unit anyarzngin sapuja caruné ring Pande 'taking a part in 
ritual ceremonies in Banjar Pande'. Tenganan Pegringsingan village is awarded the fertile nature with abundant crops, not only enjoyed by Tenganan Pegringsingan people, but also for outsiders who migrate to Tenganan Pegringsingan village to make a living. Therefore, it is appropriate that people who migrate and make a living in the village of Tenganan Pegringsingan participate in ceremonies and rituals that are carried out as a representation of harmonious relationship with God, the Creator of the universe.

\subsubsection{Destructive Ideology in the Awig-awig Text}

As explained earlier, ideology in ecolinguistics does not reveal the truth or unrighteous ideology implied in a discourse. The substantial purpose of ecolinguistic analysis is whether the ideology is appropriate or not with the underlying ecosophy of THK. In addition to the presence of preservative ideologies, there are also meanings and ideologies that tend to damage the environment, especially at the level of the social environment. The following citations are examples of destructive ideologies revealed in the awig-awig text.

(14)//yan ana wong désa ika sinalih tunggal mongambil misan, kahanggén somah, pada tan kawasa; yan ana amurug, kawənang kakésahang olih désa, tan kawasa agənah ring Désa Tenganan Pegringsingan, tur tan wanang anyungsung kayangan ring Tenganan Pegringsingan manut trap kadi saban//

(ADATP-16)

'if anyone of the villagers marries to a cousin as a wife or husband is truly prohibited. If anyone violates it, the village has a right to drive him/her away; he/she is not permitted to live in Tenganan Pegringsingan village, even not allowed to pray in the temples in Tenganan Pegringsingan based on the valid rules'

The meaning and ideology revealed in citation (14) is the confinement of one's rights in determining a life partner. In general, humans are free to determine their life partners as long as they do not violate the prevailing norms. Marriage between cousins was considered to pollute the existence of the village environment,' thus, it is necessary to be expelled from the village or forbidden to live in Tenganan Pegringsingan Village, and not allowed to worship holy places in Tenganan Pegringsingan area.

Biologically, inter-family marriages are not good, but the lingual unit kawənang kakésahang olih désa 'the village has a right to drive away'. tan kawasa agənah ring Désa Tenganan Pegringsingan 'not allowed to live in Tenganan Pegringsingan Village', tan wanang anyungsung kayangan 'not allowed to worship holy places (pura)' imply ideologies that can trigger disharmony of the social environment because they are in contrast to the ecosophy of THK. The lingual unit kakésahang olih désa 'evicted by the village', tan kawasa agənah ring Désa Tenganan Pegringsingan 'not allowed to live in Tenganan Pegringsingan village', and tan wanang anyungsung kayangan 'prohibited from worshiping holy places' are in contrast with the ecosophy of THK.

(15)//...wong Désa Tenganan Pegringsingan yaniya cucaka, tan kawasa iya milat masangkapan ring Bale Agung// 
(ADATP-29)

'...one who is disabled is not allowed to attend customary meetings in the Bale Agung 'customary meeting building' of Tenganan Pegringsingan Village'

Citation (15) implies marginalization ideologies that have the potential to cause social environments to become disharmonious. This can be observed from the lingual unit yaniya cucaka, tan kawasa iya milət masangkəpan ring Bale Agung 'if one is disabled, is prohibited from attending a meeting in Balé Agung'. Physically disabled people are marginalized from people who have normal physicality. From a critical ecolinguistic perspective, this kind of text is classified as destructive because the text producer does not give justice to the rights of a person as a member of a traditional village as the right of a normal physical person. In this case, text producers position themselves as the successors to tradition in the application of customary law, which, if examined from the eco-perspective of THK, is one of the triggers of the social environment to be disharmonic.

(16)//yan ana wong désane ring Tenganan Pegringsingan sinalih tunggal kari majangkapan tan ana madrué pianak, wənang camput, tan kawasa ngidih pianak ring anak sios, muah tan kawasa makidihang muah angadol pakawisan saluirniya pada tan kawasa//

\section{(ADATP/52)}

'If a marriage couple in Tenganan Pegringsingan village does not have any children, they are considered camput 'one who has not got any heirs'; They are forbidden to adopt any children from other people; and absolutely prohibited to grant or sell their assets'

\section{Summary}

The practice of power in the Awig-awig text of Tenganan Pegringsingan Village is explicitly represented by the form of negative modalities tan kawasa, tan wenang 'prohibited / not allowed / not permitted'. From ecolinguistic perspective (Stibbe, 2015), an analysis is carried out to investigate whether the ideologies of the awig-awig texts encourage the people of Tenganan Pegringsingan to protect or damage either the natural, social, or spiritual environment. In this study, ideologies revealed in the awig-awig text are preservative and destructive. The preservative ideology of the natural environment is in the form of preventive actions against the sale or pledge of inherited land, and the prohibition of logging trees protected by the village. The preservative ideology of the social environment is to create harmonious relations between people, gender equality, and maintain good relations with migrants. While the preservative ideology of the spiritual environment is the sincerity of making sacrifices in every ritual / ceremony. Furthermore, the destructive one is an ideology in the form of human rights violations; patriarchal; and capitalism that needs to be opposed.

\section{References}

Bang, J., \& Døør, J. (2001). Ecology, Ethics \& Communication, Dialectical Ecolinguistics: Edited by Anna Vibeke Lindø and Jeppe Bundsgaard, (53-84), University of Odense, 


\section{Macrothink}

International Journal of Linguistics

ISSN 1948-5425

2018, Vol. 10, No. 5

Denmark.

Eriyanto. (2001). Analisis Wacana: Pengantar Analisis Teks Media. Yogyakarta: PT LKiS Pelangi Aksara.

Fairclough, Norman. (1992). Discourse and Social Change.Cambridge: Polity Press.

Fairclough, Norman. (2003). Language and Power: Relasi Bahasa, Kekuasaan, dan Ideologi. (Indah Rohmani, Pentj). Gresik: Boyan Publishing.

Fill, A. dan P. Muhlhausler (eds). (2001). The ecolinguistic Reader: Language, Ecology and Environment. London: Continuum.

Gubernur, B. (2003). Peraturan Daerah Provinsi Bali Nomor: 3 Tahun 2003, Tentang Perubahan atas Peraturan Daerah Provinsi Bali Nomor: 3 Tahun 2001. Denpasar: Pemprov. Bali.

Mbete, A. M. (2014). Manfaat Kajian Ekolinguistik dalam Upaya Pelestarian Bahasa, Budaya, dan Lingkungan. Sambutan Ilmiah dalam Prosiding Seminar Nasional Ekolinguistik. Medan: Lembaga Kajian Linguistik (LKE).

Peters, J. H., \& Wisnu, W. (2013). Tri Hita Karana The Spirit of Bali. Jakarta: PT Gramedia.

Qiu, J. (2013). A Critical Study of English Eco-hotel Profiles - Based on Fairclough's Three-dimensional Model. In Theory and Practice in Language Studies, 3. (pp. 1879-1886). https://doi.org/10.4304/tpls.3.10.1879-1886

Stibbe, A. (2015). Ecolinguistics: Language, ecology and the story we live by. London and New York: Routledge.

Trčková, D. (2016). Representation of Nature in Ecotourism Advertisements. In Discourse and Interaction. (pp. 79-94). https://doi.org/10.5817/DI2016-1-79.

van Lier, L. (2004). The Ecology and Semiotics of Language Learning: A Sociocultural Perspective. New York: Kluwer Academic Publishers.

Wiana, K. (2007). Tri Hita Karana Menurut Konsep Hindu. Surabaya: Paramita

Wodak, R. (2001). What Critical Discourse Analysis is about - a summary of its history, important concepts and its development. In: Wodak and Michael Meyer, editors. Methods of Critical Discourse Analysis. London, Thousand Oaks, New delhi: Sage Publications.

\section{Copyrights}

Copyright for this article is retained by the author(s), with first publication rights granted to the journal.

This is an open-access article distributed under the terms and conditions of the Creative Commons Attribution license (http://creativecommons.org/licenses/by/4.0/) 